\title{
How to Justify Purchase of an iPad: Users of the Latest Launch
}

\author{
Emílio José Montero Arruda Filhol, Rosa Maria Chaves Lima2, Mark Michael Lennon3
}

\begin{abstract}
Contemporary technology innovation is increasingly based on convergence and the multiple uses of products. This change is detailed in the literature about new product development, as well as that on systems integration. This article focuses on the factors that determine the justification for using advanced technology products in which the perceived value of the product is not based on its functionality, as much as on its hedonistic or social value as an "all-in-one" product. In this study, consumer behaviors toward the Apple iPad are analyzed using netnographic evidence taken from internet postings by the consumers themselves. Since Apple initially marketed the iPad as a revolutionary product, with integrated services and features, our analysis concentrates on how consumers perceived these new, innovative features, in an effort to justify their purchase of the product. Our findings indicate that consumers' justifications are based not only on the iPad's functionality, but also its hedonic traits, and its similarity to the previously released innovative product, the iPhone.
\end{abstract}

Keywords: iPad; netnography; hedonism; utilitarianism; justification; new products.

\footnotetext{
1,2 Business Administration Graduate Program - PPAD. University of Amazon UNAMA. Brazil. e-mail: 'emilio.arruda@unama.br, ${ }^{2}$ rosachali85@gmail.com

${ }^{3}$ Penn State University. United States. e-mail:mml22@psu.edu
} 


\section{Introduction}

Much existing literature deals with the processes of consumer decisions and preferences. Such research includes analyses of the behavior of advanced technology consumers, investigations of systems integration, and examinations of the convergence of services in technology devices (Kim \& Sunder, 20I4; Lee \& Hill, 20I3; Han et al., 2009; Kim et al., 2005; Vrdoljak et al., 2000). This innovation market attracts experts in the development of "all-in-one" products (Nunes et al., 2000; Lee et al. 2013; Terlutter, R., \& Moick, 2013), who strive to generate a diversity of product attributes in order to help consumers justify the purchase of new technology products (Dahl \& Hoeffler, 2004; Okada, 2005; Chiu et al., 20I4).

Development in these streams of literature has been aided by the constant changes in mobile and tablet technology. These "bundled," or multiple, products, like Apple's iPad, are highly valued by consumers. While satisfying consumers' hedonic needs, the multi-purpose functionality of these types of technology products allows users to justify their purchase based on utilitarian motives (Arruda-Filho, 2012; Arruda-Filho \& Lennon, 20II; Khan \& Dhar, 20I0; Kim et al., 2005; Taylor et al., 1999; Vrdoljak et al., 2000). While possessing both utilitarian and hedonic features, most of these products are usually defined by their utilitarian value for work or study (Slama \& Singley, 1996; Leftheriotis \& Giannakos, 2014). So what differences make some devices more successful than others, as in the case of the iPad, which, when launched, saw a large number of users clamoring to have it before anyone else?

A product is defined as "utilitarian" in this study following the definitions developed by Ahtola (1985) and Slama and Singley (1996), in which a product is utilitarian if its purpose is to aid in the performance of work or study, or it possesses functions that are indispensable for the market development of an enterprise or an individual person. We further extend the definition of "utilitarian" when the products become a marker of social status for the consumer (Arruda Filho et al., 2008, 2010), despite the product's potential hedonic consumption characteristics. Katz and Sugiyama (2006) assert that consumers use their devices as part of their body, and thus demonstrate a need to publicize themselves as a special segment that is more up to date compared to the general population.

The concepts of "hedonic" and "hedonism" as used in this article refer to products that are related to desire, and are intended for the diversion, pleasure, and satisfaction of consumers. These products are important with regard to their personal, social, and identitary positioning (Chaudhuri \& Fitzgerald, 2010; Chitturi et al., 2007; Park, 2006). But when consumers are focusing on gifts to others for receivers satisfaction or pleasure, sharing their diversion in some ways becomes a matter of social status, which is defined as social value related to the usage of the product (Mittal, 2006).

Studies on consumer use and behavior show that technology users are more apt to purchase hedonic products, which offer them pleasure, rather than strictly utilitarian products (Dastan and Gecti, 20 I4; Arruda-Filho \& Lennon, 20I I; Gill, 2008; Khan \& Dhar, 2010; Park, 2006). However, consumers feel more secure about their product selection if there are also utilitarian features involved, because it is easier for them to justify the expense of the new acquisition and thereby avoid feelings of guilt (Choi et al., 2014; Arruda Filho et al., 2008; Okada, 2005).

Based on this hedonic/social, rather than utilitarian consumption, this article studies consumer' perceptions of the Apple iPad's necessity, and how important it has become. The study seeks to verify whether product preferences are related to basic questions (necessity), or to those pertaining to desire (pleasure, satisfaction), and whether purchase justification is based on utility or preference (Okada, 2005). Consumers primarily take into account factors such as ease of use (Hoch \& Deighton, 1989), social design (Katz \& Sugiyama, 2006), knowledge of the product category (Coupey, Irwin, \& Payne, 1998; Hoeffler, 2003), and purchase justification of the products they use (Okada, 2005; Park, 2006; Choi et al., 2014).

Apple's iPad, launched in 2010, is one of the most innovative and advanced technology products ever released (Hernandez \& GuoHua, 20I I; McNaughton \& Light, 20I3). Critical to its successful design is its stunningly clear 9.7-inch screen and relative affordability, as the first iPad models were priced between US $\$ 499$ and US $\$ 829$ (Auletta, 2010). The product is a multi-platform device with a highly integrated range of services: it allows the user to search the internet, play games, and watch films (Ostashewski \& Reid, 2010). The Apple iPad was selected for this study because of its high level of integration, diversity of uses, and innovation in the market, besides the fact that it was the first tablet with multifuncionality integrating the internet, games, e-reader capabilities, maps, and so on. This product readily facilitates studies of the behavior of the contemporary technology consumer, as well as of the importance of innovation, social status, and market differentiation in consumers' product choices according the convergence provided.

Following the precepts of qualitative research, where initial inquiries are exploratory in nature (Eisenhardt, 1989; Yin, 2009), in order to allow the research questions to be grounded and to emerge from the initially available data (Denzin \& Lincoln, 2005; Stake, 1995; Strauss \& Corbin, 
1998), the researchers conducted an initial review of Apple iPad customers posting on the www.everythingicafe.com website. The reason for using one specific website instead of different sources was because everythingicafe.com is a large website specifically dedicated to discussion of Apple's equipment, so that the quality and depth of content in each discussion is very impressive. Consumers use this website to obtain information about their purchase, seek advice, express doubts, and so on; the number of participants and discussions is huge, and thus provides an opportunity to obtain the best context for analyzing the researchers' argument (Kozinets, 2010).

From this review, three main research questions emerged:

I. What justifies purchase of the iPad?

2. Which categories of consumers are responsible for the iPad's success?

3. How does the existence of earlier products influence justifications?

The remainder of this study is divided into the following sections. First, the Theoretical Framework: Consumption and Innovation section describes the framework created, citing relevant literature. Key themes are explained, including differences between bundled and single-use products, hedonic and utilitarian values, fashion, and brand loyalties. In the Methodology section, the use of netnography is described as applied to the iPad discussion groups and the selection of www.everythingicafe.com. The Results section summarizes the data collected and identifies major themes, illustrating these through extended quotes from the transcripts. This analysis is then used to answer the research questions. Finally, in Discussion and Conclusions, the impact of these findings for practitioners and future research is described.

\section{Theoretical Framework: Consumption and Innovation}

\section{Integrated versus Single-Purpose Products}

Recent research indicates a growing correlation between innovation and integrated technology products, as opposed to single-purpose products (Lee et al., 2013; Gill, 2008; Han et al., 2009). With a greater range of opportunities, consumers are confronted with difficult choices that imply three options: opting for single-purpose products, selecting convergent products, or even choosing both. This fight for space in the market is related to the performance of the products, where multi-purpose products offer greater benefits compared to their single-purpose competitors (Gill, 2008).

Integrated products, such as tablets, which offer features as diverse as e-reader capabilities, internet browsing, video recording, a music player, and still photography, are popu- lar with consumers because they offer greater benefits compared to simple, single-use products such as dedicated e-readers (Auletta, 2010; Burrell, 2010). This comparison is defined by the impact of the integrated product on consumer choices. The greater number of functions in a single device arouses consumer interest because it promises greater uses due to its wide range of attributes (Harris \& Blair, 2006; Nunes et al., 2000).

This preference for integrated products is also related to their portability - a possibility that has led to important developments in the telecommunications market, and is reflected in mobile communication devices that allow for greater mobility through a reduction of the number of devices that need to be carried by any one user ( $\mathrm{Han}$ et al., 2009; Kim et al., 2005). Apart from mobility and multiple uses (this latter resulting in a higher perception of benefits), these integrated products are more attractive to consumers as they appear to imply less risk (Sarin et al., 2003), since users believe that they will gain more use out of a new technology product that has a wider range of functions. Thus, the risk that they will not get their money's worth out of the new product is diminished. Additional studies have empirically demonstrated that a device that is integrated, and provides a range of services, has a greater market presence compared to single-purpose products (Hobday et al., 2005; Pathak, 2005).

Other studies have shown that this perception of decreased risk (and with it a decreased propensity for the manifestation of buyer's remorse) is reduced when users possess little knowledge of the product category (Harris \& Blair, 2006). With more complex, multiple-use products, consumers cannot accurately gauge the efficacy of the multifunctionality of these all-in-one products (Terlutter and Moick, 2013; Arruda-Filho et al., 20 I0;Arruda-Filho \& Lennon, 20I I; Knotts et al., 2009). Therefore, consumers seek the greatest amount of information about the product at the moment of purchase so as to feel satisfied about their choice. What is important is identifying product attributes that justify purchase, even if these attributes are not ultimately used by the consumer (Arruda-Filho \& Lennon, 20I I; Han et al., 2009).

\section{Hedonic versus Utilitarian Products}

Contemporary technology products are increasingly focused on the integration of features, be these utilitarian (e.g., calculators, calendars/day planners, GPS maps, etc.), hedonic (e.g., still cameras, video recorders, MP3 players, etc.), or social (e.g., characteristics providing consumers with status as a Prada mobile). Given this, in this study we analyze the way in which these integrated attributes involve functional or hedonic uses, and how these attributes provoke a mix of positive and negative emotions for the consumer. 
These emotions may include feelings of anxiousness, guilt, sadness, happiness, disappointment, confidence, and/or security; thus, in this study we are interested in how these emotions affect consumers' perceptions and product choices (Chitturi et al., 2007).

Okada (2005) demonstrates that people naturally seek enjoyment and, because of this desire for fun, search for satisfactory relationships with products and services in order to liven up their daily routines. However, the process of product choice is generally defined by the effort to acquire the best product at the cheapest price, taking into account the consumer's bargaining power. When a product possesses diverse attributes, the augmentation of hedonic integrations to a utilitarian base (e.g., a cell phone added to a camera) allows for a greater perception of product value. On the other hand, the same cannot be said of a utilitarian integration to a hedonic base, as this does not add to the primary consumer value of the hedonic product (Gill, 2008).

In products of opposing characteristics, such as those that are more oriented toward leisure activities (hedonic) and those that are more focused on functionality (utilitarian), there is a strong preference for hedonic products when these are presented individually. However, when the consumer is confronted with a hedonic versus a utilitarian product, there is a need to justify their decision (Okada, 2005). Because the lack of a utilitarian function in the product may cause a sense of guilt in the consumer (Spaid \& Flint, 2014; Okada, 2005; Park, 2006; Van der Heijden, 2004), in order to avoid this emotion consumers try to justify their hedonic choices by citing utilitarian reasons for purchase (Arruda-Filho et al., 20I0).

\section{Fashion and the Social Aspect of Use}

Technology products are often used as a way of showing a consumer's lifestyle, identity, and world-view, as affirmed by Katz and Sugiyama's (2006) study of mobile phone consumers in Japan and the United States. Products are used as symbolic expressions of identity (Eisenman, 2013; Stein et al., 20/3), and, in the case of mobile phones, can become almost a physical extension of the consumer's being (Lennon, $20 \mathrm{I0}, 20 \mathrm{lla}, 20 \mathrm{llb}$ ). Thus, fashion and technology interact, allowing the consumer to use electronic devices in a personal manner, and incorporating these as part of a personal aesthetic. These consumers are able to create a strong sense of personal and social identity through the use of technology (Kozinets, 20I0).

Of course, given the constant change in fashion and the necessity of launching new electronic products with higher levels of design sophistication, the functionality of these products becomes less valued over time. What generates value is the image of the product, with consumption reflecting personal and social values, thereby allowing consumers to express their cultural identities through the possession of material goods (Belk \& Tumbat, 2005; Belk, Wallendorf \& Sherry, 1989; Chitturi et al., 2007).

If possessing a technologically advanced and visually attractive electronic device is a way for consumers to express their identities, then it is also important that they remain current as updates become are available to newer, more sophisticated products, which can also potentially be possessed by their fellow consumers. This status and peer pressure are important factors in the moment of consumer choice (Goldsmith, Clark, \& Goldsmith, 2006; Andorfer \& Liebe, 20I3).

People do not buy mobile technology merely for its functional qualities, or for the way in which it helps them perform daily tasks or improve communication. Rather, they also adopt new technologies even if there have been only minor updates, so long as these changes are significant enough to alter the concept of the device as a tool, or if the change incorporates a new use or unique feature (Katz \& Sugiyama, 2006). Thus, the continuous search for new devices, which entails an evaluation of the newest innovations on the technology market, is a constant factor in technology consumption, where fashion is a motive for the adoption of new technologies. In this sense, the symbolic aspect of fashion is due to the fact that users show and understand their identities through the use of the products they possess (Belk, I 988; Meng, 2005).

\section{Communities Who Show Brand Loyalty}

Brand loyalty is characterized by a group of people who share an interest in the brands they buy (Muñiz \& O'Guinn, 200I).These groups are not linked by geographic proximity, but rather are structured as a group of admirers of a particular brand. The loyal consumer intensely identifies with the values of the brand, and becomes a stout defender of the company's ideology. Often, they act in a missionary capacity, attempting to convert others to the brand (Pimentel \& Reynolds, 2004). The object of their efforts is often to tempt others to form part of a social group, in which the members identify themselves through the same shared interests and relate effectively to their fellow consumers (Belk \& Tumbat, 2005).

These elements of brand loyalty become more important than the value of the good consumed, or even than the perception of utilitarian and commercial value (McCracken, 1986), so that they eventually reach the level of extreme fidelity, and even become capable of transcending self-interest (Belk, Wallendorf, \& Sherry, 1989). In cer- 
tain cases, this loyalty can survive even if the company has grave faults, suffers bad publicity, experiences administrative problems, or has elevated prices (Pimentel \& Reynolds, 2004; Alonso-Almeida et al., 20l4).

Belk and Tumbat (2005) show that consumer loyalty has a similarity to religious devotion. The authors analyzed a group of Apple Macintosh consumers and identified various myths regarding the company: the myth of creation, the messianic myth, the satanic myth, and the myth of resurrection, all of which are present in various cultures. The authors also observed how the leader of Apple, the late Steve Jobs, employed a type of charismatic leadership similar to that of leaders of religious cults. Given this, it is important to evaluate the consumption of a particular product, and the point at which loyal consumers prejudice, or foster the acceptance of, new products on the market, thereby creating a positive image of the product, or forming new, loyal, groups for the adored device.

\section{Methodology}

The object of this study is Apple's "tablet" device, the iPad. This choice was based on market preference, since, during the period of its launch, the product was positioned as the brand identifier in terms of choice of purchase and use. Another important factor is related to the fact that, during the period of pre-launch and sale, this product was highly sought-after because of its highly valued position as an advanced technology product, which differentiated it from other offerings on the market and defined it as a truly new consumer product (Hoeffler, 2003).

During the launch period, the iPad was positioned as an innovative product (Bass, 1969; Rogers, 2003), and consumers underwent a process of acquainting themselves with this new technology (Auletta, 2010; Ostashewski \& Reid, 20I0), which brought with it many loyal Apple customers and consumers of other, similar products that were not able to compete with the iPad.

The research methodology for this study is netnography - a coin termed by Kozinets (1997) in his ground-breaking research on the consumption patterns of a unique American subculture: ardent science fiction fans of the hit television show The X-Files. After an ill-fated attempt to conduct a traditional ethnographic study using graduate students to interview fans attending the annual science fiction and comic book conference "Comicon" (at which many of the wouldbe subjects were dressed as their favorite comic book and television heroes), Kozinets developed a unique and novel approach of indirectly learning about the subculture through the examination of this group's online discussions.Thus,"nethnography" (later shortened to "netnography") was born.
By taking information from web blogs and discussion forums on a predetermined cultural or social theme, consumer behavior can successfully be analyzed (Kozinets, 2002, 2010). The participants in the blogs or forums studied are either experienced contributors or simple participants in search of information. The blogs/forums selected must be of high credibility, in order to legitimize the comments of the participating consumers.

The most important aspect of the use of netnography is related to the fact that the internet is an open space in which people are able to express satisfaction or dissatisfaction with purchases made, and the use of these purchases. In this analysis of acceptance, consumer decision is evaluated, which is associated with the social and hedonic factors that influence this preference. In addition, it is important to identify and interpret the level of discussion collected on the chosen blogs/forums (Kozinets, 20I0).

Data for the study was extracted from the website www. everythingicafe.com, an extremely popular Apple users' website. This choice was justified by the company's noninterference with regard to the comments of users, whether these comments are positive or negative.As Apple has a system that allows it to receive feedback from consumers in order to correct errors and identify market successes, this site serves as a base from which to collect information on both satisfied and unsatisfied customers. Apple employees use customer feedback to optimize services and the functioning of its products on the market (information provided by the website). The site contains an average of 20,000 discussions on various Apple product offerings. This therefore gives researchers the opportunity to choose the best group discussions that entail a large number of participants helping, explaining, debating, agreeing, and not agreeing with others, and which demonstrate sufficient richness of contributions to analyze the context being researched (Kozinets, 2010; Cromie and Ewing, 2008; Yim, Tse, \& Chan, 2008; Braunsberger and Buckler, 2009).

The material for this research study consists of 23 pages of text in Microsoft Word format, drawn from postings to the everythingicafe.com website. These postings were used for interpretation, and arranged in such a manner that the top two-thirds of the page consisted of the actual postings, with the bottom third allowing room for analysis and coding of the entries. Details about this primary data are presented in Table I. 
The coding developed is the same as that used for any model of qualitative ethnographic study that does not use automatically generated coding software. Initially, the researcher read through all of the information collected, highlighted relevant passages, and developed keywords that succinctly summarized the sentiments expressed in the postings. The researcher then translated his understanding of the consumers' descriptions into phrases or words that identified the type of consumption or the value associated with the textual descriptions.After this first level of coding was completed, an additional researcher carried out a second coding. From this, categories were created to describe similar results. The type of threads used, and the number of individual and total posters, can be seen in Table 2.

In Table 2, the single posters are the number of participants in the discussion, which is 102 , as opposed to the total number of contributions, equaling 144. This difference in numbers is due to the fact that individual participants can post comments more than once in the same discussion. Based on the data collected, headlines were created in relation to the specific groups of consumers for this type of technology. The authors also revised the data individually (to understand individual author perception) and when it is finished, together (composing authors' interpretation) by coding and evaluating the content, so that they could then integrate and interpret the categories of consumer that best represent the users of these innovative products.
After the data analysis, the headlines were constructed as keywords relating to the content of each categorization, which allowed for the creation of a description regarding how future consumers and product users behave, and their expectations of innovative and ground-breaking new technologies.

The excerpts taken from the posters were each presented under a headline, including the page and line number of the material taken from the 23 pages. Starting from the literature on consumer behavior, a comparison was made with the interpretative analysis, using as a reference the observations of the researchers and the data from the existing literature.

\section{Results}

In evaluating the discussions collected in relation to the iPad, five headlines were developed that describe the principal groups of consumption categorized by this research. These headlines clearly identify the values of each individual group, the perceptions of the iPad's benefits, and the consumers' concerns and disappointments.

For each headline created, the significance of each proposed category was identified and placed next to the main contents from the posts, in order to describe the behavior of

\begin{tabular}{|l|l|}
\hline Name of Site & EverythingiCafe (Apple's Product Forum) \\
\hline URL & http://www.everythingicafe.com/ \\
\hline Data-collection period & March 12 to September 18, 2011 \\
\hline Data checked & Threads relating to the launch of the iPad \\
\hline
\end{tabular}

Table I. Primary Data of the Survey Carried Out

\begin{tabular}{|l|l|l|l|l|l|}
\hline Number & Name of Thread & Title of Discussion & $\begin{array}{l}\text { Number } \\
\text { of single } \\
\text { posters }\end{array}$ & Total posters & Words \\
\hline 1 & Eagerness pre-launch & $\begin{array}{l}\text { Official: I just pre-ordered } \\
\text { an iPad }\end{array}$ & 45 & 62 & 3187 \\
\hline 2 & Surprise with the device & $\begin{array}{l}\text { I'm so freakin excited about } \\
\text { the iPad }\end{array}$ & 24 & 35 & 1860 \\
\hline 3 & Justification of the iPad & $\begin{array}{l}\text { How will you justify the } \\
\text { iPad? }\end{array}$ & 33 & 47 & 3254 \\
\hline Total & 102 & 144 & 8301 & & \\
\hline
\end{tabular}

Table 2. Division of Threads for Research

ISSN: 07I 8-2724. (http://www.jotmi.org)

Journal of Technology Management \& Innovation (c) Universidad Alberto Hurtado, Facultad de Economía y Negocios. 
the participants. In turn, these were compared with the existing literature, enabling us to construct a coherent framework for analysis and interpretation. Thus, the characteristic types of technology consumers were evaluated, together with their homogeneous or heterogeneous values, and the perceptions of benefits regarding convergence and justification for product usage described. Each post detailed below notes the page number and line on which the discussion occurs in the original document compiled for the analysis.

\section{Is the iPad a Necessity?}

In this group of consumers, the users show a high level of interest in the uniqueness of the product, which reflects the previously untried attributes of the new product. These posts clearly show problems related to social anxiety (Reid \& Reid, 2007) as consumers exhibit a desire for the new device, but also a necessity for justification (Okada, 2005; Palazon \& Delgado-Ballester, 20I3) to purchase the equipment.

"I doubt many of us, if any, truly NEED an iPad. I will agree though if it fills your needs and will not put you in a financial hardship, then why not get it." P.I8, L 25-26.

"But the iPad that has multiple uses, runs all my apps, and surfs the net is much more than an e-reader. But at this point, already having a netbook, I'm having a hard time justifying getting an iPad, though I am definitely interested." P.I0, L I4-I7.

"If $i$ get one there are only 2 reasons $=$ ibooks, which $i$ was about to get a kindle for until this started to get rumored, and web surfing, which seems like it would be a lot of fun on a big apple touch screen." P.7, L 50-53.

"However, I am not one to talk since I also have a laptop and an iPhone and don't really need the iPad but plan on buying one." P.I8, L 6-9.

Some users, whether through a need to justify their purchase or through self-delusion, imagined that all of the product's attributes would be important for all their requirements, which agrees with earlier research (Gill, 2008). Diversion and status form part of this perceived necessity to purchase the iPad, which illustrates that hedonic and social value are intrinsic aspects of the product. Thus, consumers reveal some confusion about whether the purchase of the product is truly necessary (Veryzer \& Borja de Mozota, 2005).

\section{Desperate to be the Latest User}

Many consumers expressed a desperate desire to obtain and use the product. This desire often bordered on the unreasonable, with many customers complaining about having to wait a few days for product delivery, and even discussing the exact time of the product's arrival. This presents a specific kind of user that searches for social positioning through obtaining an innovative product before others.

"I have no problem selling my wifi iPad in a month and getting a $3 g$. I'm going to wait until I see what's up with the HP Slate. I just had to have an iPad the moment they came out. It's a disease." P.I4, L 23-27.

"I have both shipping and store reservation, I will cancel one of the two when I decide what to do, at least this way I'm covered!” P.6, L 28-30.

During the pre-launch period, consumers were extremely anxious, almost like children waiting for Christmas. They were careful to arrange the most rapid delivery, with some reserving two or three types of delivery in order to have the product before other people. Some consumers even bought product paraphernalia before having the product itself, perhaps to reduce their impatience to have the product. Similar behavior has been seen in earlier research related to mobile phones and texting (Reid \& Reid, 2007).

However, overall, the most important point is that customers showed themselves to be absolutely frantic while waiting for the iPad. For these future users, obtaining the product before others was more important than using it. The possession of this idealized product, as an extension of the self (Mittal, 2006), represents a way in which the consumers could achieve self-actualization; consumption thus becomes a means of communication through which identities are constructed (Belk, 1988).

\section{Prior Experience with the iPhone}

Many users imagined that the iPad would be a type of elaboration on the iPhone. The intention to buy therefore arose for these users as a result of previous experience (Coupey, Irwin, \& Payne, 1998; Hoch, 2002; Arruda-Filho et al., 2010) with the iPhone. This prior experience generated a more favorable disposition to the new product on the market. These consumers could more easily imagine how they would use the features of the new product (Hoeffler, 2003; Klein \& Jakopin, 20I4).

"think of all the great iPhone apps, then think of what some of the developers can do with a faster processor and bigger screen...l'm excited." P.9, L 7-9. 
"I'm so freakin excited about the iPad. I can't wait till the 3rd. I don't know why. Some of it's just 'l'm get new electronics!' I'm not a Mac user. But I do love the iPhone. I am planning on weighing the iPad against the HP slate. Some of it's I don't think anyone else I know is getting one, so I get to show off." P.I3, L 3I-36.

The previous experience with the iPhone inspired these customers to buy the iPad, as many users transferred their experience of the previous product to the new one (Beverland et al., 2010). As the iPhone had generated massive sales and acceptance (Arruda-Filho et al., 20I0), consumers believed that they would receive similar benefits from the iPad. The larger screen size allowed consumers to imagine the possibilities of enjoying applications such as games, the internet, and video (hedonic features) in the context of the previous product (Arruda-Filho \& Lennon, 20I I).

The previous experience with the iPhone helped to justify the purchase of the iPad in another unexpected manner. Because of the iPhone's simple-to-use, haptic, and intuitive interface, consumers correctly speculated that the iPad interface would be similar, and thus just as easy to use. As earlier research by Mukherjee and Hoyer (200I) shows, the easier a novel product is to use, the more widely it will be adopted.

Customers loyal to the brand were defenders of the product, as they had already had experience of a similar product from Apple. Since they were fans of the iPhone, they were willing to become fans of the iPad, thereby demonstrating that the "Cult of the Macintosh," as first identified by Belk and Tumbat (2005), is alive and well.

\section{Device Usage Justification}

The buyers of the iPad justified their purchase with the argument that the product is an intermediary to other technologies. Many users already had a laptop to search the internet, watch films, and listen to music. They justified the purchase of the iPad because it allowed them to use the internet with greater ease, as the platform and mobility of the new device were better than those of a notebook or netbook. The innovation thus met the needs of the target public (Rogers, 2003; Kim et., 2014).

"The iPad will just be so easy to setup and use VS a laptop or netbook." P.I8, L 45-46.

"I have a sneaking suspicion that I'm going to go ahead and by the wi-fi only version when it comes out and then return it at the very end of the return period (and pay the restocking fee) just to have one for a little while before the $3 \mathrm{G}$ version comes out. How sad is that?" P.15, L 13-17.
"I am basically going to be using the iPad as an e-reader, but the other functions will keep me using it on a consistent, everyday basis. I have my Macbook Pro with me most of the time and my iPhone with me all the time. However, I can see myself taking my MBP with me less and having my iPad with me more often. The iPhone will be relegated to music, phone and internet use when I don't have Wi-Fi for my iPad. I will probably turn automatic download off for email on my iPhone and do most of my mobile email and internet use with the iPad." P.6, L 50-57.

"I dont feel i need to justify getting it, i never really splurge when it comes to tech, i have a old desktop, and a $\$ 250$ netbook...over the past month $\mathrm{i}$ have been saving to get the iPad...it will replace my netbook." P.20, L I8-2I.

Based on these commentaries, it can be understood that future users predict that they will use an integrated device more if it will address more of their requirements (Nunes, 2000). They believe that buying the iPad will mean that they will make less use of other Apple products, such as the MacBook Pro or iPhone. It remains to be seen whether this is simply a justification employed by the consumer who aspires to obtain the product and looks for explicative criteria, or whether it is a consequence of a category of use of the new product (Hoeffler, 2003).

\section{Preference for All-in-One Products}

Consumers prefer to buy technologies with a high degree of integration (Harris \& Blair, 2006). They judge each product by the number of services included (Nowlis et al., 2004). Given the hedonic factors integrated into convergent products, it is clear that the number of consumers is constantly renewed (Danaher et al., 200I). Multifunctional products are more valued by consumers when they are uncertain about the product category (Harris \& Blair, 2006). These potential iPad consumers correctly perceived that there were multiple features in this novel device, yet they could not judge either their application or their efficacy (Nunes, 2000).

In this context, consumers evaluate different information in the process of buying the technology, and look for satisfaction in use even though the attributes and features of the product might not ultimately be used. The most important objective is to find the attributes of the product that differentiate it from other products on the market, thus justifying the choice of device (Han et al., 2009).

"I can see how it will be a middle device for me. I had a Kindle 2 and returned it to see about the iPad. Pretty sure I'm going with the $32 \mathrm{gb}$ model. Movies will be a plus, but not a huge consideration for me. I don't travel a ton, but when I do, movies will be on my iPad. Music will not be on there. Don't see a need or big use for that as l'll still have my iPhone with me." P.7, L. I5-22. 
"I will primarily use it for Email and Safari and Pics. I will probably buy a few books for road trips and maybe a few tester apps. My main 2 reasons are awesome web surfing and movies. For my needs it is a laptop replacement, but I know that's not true for all.' P.9, L7-13.

The hedonic and utilitarian attributes integrated into the single product generated different emotions in consumers, which influenced their perceptions and choices (Chitturi et al., 2007). When they were confronted with a decision related to buying products with various features, both utilitarian and hedonic, purchase justification was necessary due to the lack of practical use for a hedonic product (Okada, 2005). If the product is pleasurable, and aimed mainly at providing diversion, consumers feel guilty for buying it (Okada, 2005; Park, 2006; Van der Heijden, 2004). Therefore, it is easier to justify the acquisition of a product when it is seen as utilitarian (Okada, 2005), or possesses more functional attributes, compared to if the preference is for products that provide benefits related to pleasure and diversion (Gill, 2008; Park, 2006).

Integrated products that are not easy to use, where the innovative integrations are seen as complex or unknown for the majority of users (Coupey, Irwin, \& Payne, 1998), are not seen as innovative by consumers (Mukherjee \& Hoyer, $200 \mathrm{I}$ ). In contrast, if a product is seen as mobile, the user believes that the mobility will provide wider benefits. This mobility generates a reduction in the number of devices required, thereby granting the product an exaggerated necessity status, which in turn helps to justify purchase (Kim et al., 2005; Taylor et al., 1999).

In answer to the first research question - "What justifies purchase of the iPad?" - this study shows that the reasons are complex. The multi-functionality of the iPad engenders "multiple justifications." For every new function integrated into the product (including its applications), more discussions arose surrounding the use of the device. The number of integrations in the product had a direct relation to the number of consumers, because for each individual desire there was a corresponding function or service in the iPad tablet.

Given that the great innovation of highly integrated products is that they please many different types of user, it is interesting to note that technologically integrated products tend to increase the number of consumers for the product, principally because of its hedonic features. This means that the same product can have both utilitarian and hedonic consumers, who purchase it for different reasons. Thus, the integrated product has greater market potential, with each integrated item fulfilling a different need for the various social groups analyzed. This finding extends earlier scholarly efforts, in that users demonstrated in their discussions an interest in possessing an iPad in order to "show off" to other consumers (social positioning), where the product therefore becomes an extension of themselves (Belk, 1988; Katz \& Sugiyama, 2006). The users were excited about the fact that they could use the innovation in a variety of ways.

This active pursuit of new uses for this multi-functional product answers the second research question. User postings to the discussion board indicate that most consumers did place a high value on the hedonic uses of the iPad. These include the pleasurable aspects of the haptic and graphically rich interface, and the ability to play videos, music, and games. However, in the course of making these hedonic justifications, the potential iPad consumers were also actively searching for utilitarian reasons to purchase the product. They needed to prove to themselves that the new iPad would not just be a toy, but also a useful device. Other consumers focused their need on the technology involved because they had other requirements for purchasing the device. In general, the consumers were also looking for the identity of being part of a different group, or being the first group to have the device, so that the multiple attributes integrated into one device were perceived as giving opportunities to different categories of users, for different purposes, thereby increasing users' connectivity.

Both utilitarian and hedonic consumers displayed a great desire for the product before its launch. In terms of use, as both brand loyalty and experience of previous products from the same company had given users feelings of pleasure, which were directly related to the social factor of being seen as being different from other people. Thus, the social factor can be seen as a fundamental aspect of their decision to purchase and use the product. Consumers need to display their newly acquired possession so that their peers know they own it, and to remain at the vanguard of their society. Therefore, the hedonic factor is a differential element of the product, since it elevates the perceived benefits of the product by engendering satisfaction and pleasure, thereby automatically increasing its perceived value for its users.

Finally, the existence of earlier products, specifically the iPhone, clearly had an impact on the potential iPad users. While the novel iPad is a highly sophisticated and technologically advanced product, a precedent had been set by the easyto-use iPhone. Paradoxically, consumers viewed the iPad as having low complexity, and so were not fearful of purchasing it. This is consistent with findings by Mukherhjee and Hoyer (200I). Hence, loyal brand followers defended the iPad not merely because of its attributes, but also because of their previous experiences with the iPhone. 
Apple consumers had already successfully created viable justifications for purchasing their iPhones. By and large, the posters were pleased with these purchases. Therefore, by identifying the similarities of the products (e.g., haptic interface, existing Apple iTunes and App Store distribution system, etc.) it was far easier for them to speculate on the functionality and probable usage, both hedonic and utilitarian, of the new iPad (Dastan \& Gecti, 20 I4; Kim et al., 20 I4). Hence, their new justifications could readily be derived from their old ones.This finding also confirms those of earlier research (Belk \& Tumbat, 2005; Coupey et al., 1998; Hoeffler, 2003; Klein \& Jakopin, 2014) about product acceptance based on familiarity with existing product lines and bundled services.

\section{Discussion and Conclusions}

This article consists of a study of the consumer preference for, and usability of, Apple's "tablet," the iPad, during the period of its launch on the American market. The iPad possesses a large number of hardware integrations and software services, very similar to the iPhone. It was also designed to allow access to the internet, games, and the video-sharing website YouTube, as well as GPS functionality such as maps of cities featuring restaurants and important sites, plus email, stock exchange data, MP3 playback capabilities, and an e-reader, among others.

Since this product was the first tablet device on the market to feature integration and multi-functionality, it was especially attractive to its first users (innovators), since it was marked by differences in terms of not only technology, but also status for innovators, or early adopters (Rogers, 2003). However, while consumers wanted to buy the iPad at its launch, they experienced difficulties in terms of justifying their preferences for, and use of, the product. Brandloyal customers showed an affective relationship to the new product (Alonso-Almeida et al., 20I4). The brand provoked such a high level of devotion among consumers that they imagined that the features of the iPad were superior to similar features in other products, even before these were launched on the market.
These findings have a number of implications. From a practitioner viewpoint, the findings may be useful for companies responsible for the development of new technology products, which could use hedonic characteristics to determine factors in the creation of new technologies. Because of the ability of one product to pave the way for another, companies could create marketing plans for the development, implementation, and release of successive technology products. Each successive product could build on consumers' previous positive experiences by incorporating similar features. However, companies should not forget that a high-tech product, in order to have a presence in the market, should also possess a high level of utilitarian integration, as this can serve as a justification for consumption.

From an academic perspective, this study helps shed light on the process of product justification by consumers of hightechnology products. The results validate earlier research regarding hedonic and utilitarian motives in consumer buying decisions, while expanding the field of inquiry into a brand new product. The study also helps to illustrate the phenomenon of transferring justifications for a previous product (the iPhone) onto a new product with attributes that are perceived to be similar. Thus, this opens new avenues for research and exploration.

There are of course limitations to this study. First, it examines the adoption of just one product, the iPad, during its initial release. Further, the research questions were selected from online discussions that tended to present the factors for discussion and evaluation based on the results of keyword searches. Hence, this netnographic approach is far more passive than traditional ethnography. Nevertheless, this study suggests several directions for future research.

In a more in-depth study, researchers could potentially participate in these online discussions directly, and pose a series of pre-defined questions. Likewise, new studies using both quantitative and qualitative research could be carried out with other technology products, or even later versions of the iPad itself. These studies could evaluate the hedonic and social factors of different products, in order to elucidate, for both practitioners and academics, consumers' new modes of product utilization. These findings could be of great value, as with the accelerated pace of technology and product development, consumers are becoming increasingly capable of discovering and adopting products that bring additional pleasure and enjoyment to their lives. 


\section{References}

AHTOLA, O. T. (1985). Hedonic and utilitarian aspects of consumer behavior: An attitudinal perspective. Advances in Consumer Research, I2(I), 7-I0.

ALONSO-ALMEIDA, M. D. M., Bernardo, M., Llach, J., \& Marimon, F. (20I4). Building loyalty through functional and hedonic quality. Industrial Management \& Data Systems, I I 4(3), 387-404. DOI:I0.I 108/IMDS-06-2013-0278.

ARRUDA-FILHO, E., Cabusas, J., \& Dholakia, N. (2008). Fator social versus tecnologia utilitária: Marketing social versus marketing utilitário. Revista de Gestão da Tecnologia e Sistemas de Informação, 5, 305-324.

ARRUDA-FILHO, E.J. M., Cabusas, J.A., \& Dholakia, N. (2010). Social behavior and brand devotion Among iPhone innovators. International Journal of Information Management, 30, 475-480. DOI: 10.1016/j.ijinfomgt.2010.03.003.

AULETTA, K. (2010). Publish or perish; can the iPad topple the Kindle, and save the book business? The New Yorker, 86, 24.

Bass, F. M. (1969). A new product growth for model consumer durables. Management Science, 15, 215-227. DOI: 10.1007/978-3-642-5 I565-I_107.

BELK, R.W.( (1988). Possessions and the extended self.Journal of Consumer Research, 15, 139-168. DOI:10.1086/209|54 Belk, R. W., \& Tumbat, G. (2005). The cult of Macintosh. Consumption Markets \& Culture, 8, 205-217. DOI: $10.1080 / 10253860500160403$

BELK, R. W., Wallendorf, M., \& Sherry, J. (1989). The sacred and the profane in consumer behavior: Theodicy on the Odyssey. Journal of Consumer Research, 16, I-38. DOI:10.1086/209191

BEVERLAND, M. B., Napoli, J., \& Farrelly, F. (2010). Can all brands innovate in the same way? A typology of brand position and innovation effort.Journal of Product Innovation Management, 27, 33-48. DOI: I 0. I I I /j. I 540-5885.2009.00698.x

BRAUNSBERGER, K., \& Buckler, B. (2009). Consumers on a mission to force a change in public policy: $A$ qualitative study of the ongoing Canadian seafood boycott. Business and Society Review, II4 (4), 457-489. DOI: I0.I I I I/j. I4678594.2009.00350.x
BURRELL, I. (2010). Can Apple save the written word? Newspapers and magazines hope new computer will do for them what the iPod did for the music industry. The Independent, 23 January, Downloaded on February, 2013. http:// www.independent.co.uk/life-style/gadgets-and-tech/news/ can-apple-save-the-written-word- 1876399.html.

CHAUDHURI, A., \& Fitzgerald, T. R. (2010). Emotional responses upon initial exposure to a hedonic or utilitarian description of a radical innovation. Journal of Marketing Theory and Practice, 18, 339-359. DOI: 10.2753/mtp I0696679180403

CHITTURI, R., Raghunathan, R., \& Mahajan, V. (2007). Form versus function: How the intensities of specific emotions evoked in functional versus hedonic trade-offs mediate product preferences. Journal of Marketing Research, 44, 702-7|4. DOI: I0.I509/jmkr.44.4.702

CHIU, C. M., Wang, E. T., Fang, Y. H. and Huang, H. Y. (20I4). Understanding customers' repeat purchase intentions in B2C e-commerce: the roles of utilitarian value, hedonic value and perceived risk. Information Systems Journal, 24(I), 85-I I4. DOI: I 0. I I I Ij. I365-2575.2012.00407.x

CHOI, J., Li, Y.J., Rangan, P., Chatterjee, P., \& Singh, S. N. (20I4). The odd-ending price justification effect: the influence of price-endings on hedonic and utilitarian consumption. Journal of the Academy of Marketing Science, published online. DOI:I0.1007/s I 1747-0|4-0369-6

COUPEY, E., Irwin, J., \& Payne, J. (1998). Product category familiarity and preference construction. Journal of Consumer Research, 24, 459-468. DOI: 10.1086/20952I

CROMIE, J., \& Ewing, M. (2008). Squatting at the digital campfire: Researching the open source software community. International Journal of Marketing Research, 50(5), 63I-653. DOI: $10.250 \mathrm{I} / \mathrm{s}$ | 470785308200079

DAHL, D., \& Hoeffler, S. (2004). Visualizing the self: exploring the potential benefits and drawbacks for new product evaluation. Journal of Product Innovation Management, 2I, 259-267. DOI: I 0. I I I I/j.0737-6782.2004.00077.x

DANAHER, P., Hardie, B., \& Putsis, W. Jr. (200I). Marketingmix variables and the diffusion of successive generations of a technological innovation. Journal of Marketing Research, 38, 50I-5 I4. DOI:I0.1509/jmkr.38.4.50I.I8907

DASTAN, I., \& Gecti, F. (20I4). Relationships among utilitarian and hedonic values, brand affect and brand trust in the smartphone industry. Journal of Management Research, 6(2), |24-|39. DOI: |0.5296/jmr.v6i2.526 |

ISSN: 07I 8-2724. (http://www.jotmi.org) 
DENZIN, N. K., \& Lincoln,Y.S. (2005).The Sage Handbook of Qualitative Research.Thousand Oaks, CA: Sage.

EISENHARDT, K. M. (1989). Building theories from case study research. Academy of Management Review, 14, 532550. DOI: |0.4|35/978|4|2986274.n I

EISENMAN,M. (2013). Understanding aesthetic innovation in the context of technological evolution. Academy of Management Review, 38(3), 332-35I. DOI: I0.5465/amr.20II.0262

GILL, T. (2008). Convergent products: What functionalities add more value to the base? Journal of Marketing, 72, 46-62. DOI:10.1509/jmkg.72.2.46

GOLDSMITH, R., Clark, R., \& Goldsmith, E. (2006). Extending the psychological profile of market mavenism. Journal of Consumer Behaviour, 5, 4II-4I9. DOI:10.1002/cb.189

HAN, J. K., Chung, S.W., \& Sohn, Y. S. (2009). Technology convergence: When do consumers prefer converged products to dedicated products? Journal of Marketing, 73, 97-108. DOI: 10.1509/jmkg.73.4.97

HARRIS, J., \& Blair, E. (2006). Functional compatibility risk and consumer preference for product bundles. Journal of the Academy of Marketing Science, 34, 19-26. DOI: 10.1 I 77/009207030528I708

HERNANDEZ, J., \& GuoHua, Y. (20I I). Is it just technology or other else behind Apple? Study of marketing strategy for iPad launching as its new innovative product. 2nd International Conference on Business and Economic Research (2nd ICBER 20I I), Langkawi Kedah, Malaysia: Conference Master Resources.

HOBDAY, M., Davies, A., \& Prencipe, A. (2005). Systems integration: A core capability of the modern corporation. Industrial and Corporate Change, I4, II09-II43. DOI:10.1093/ $\mathrm{icc} / \mathrm{dth} 080$

$\mathrm{HOCH}, \mathrm{S}$. (2002). Product experience is seductive. Journal of Consumer Research, 29, 448-454. DOI: I0.1086/344422

HOCH, S., \& Deighton, J. (1989). Managing what consumers learn from experience. Journal of Marketing, 53, I-20. DOI: $10.2307 / / 25 / 410$

HOEFFLER, S. (2003). Measuring preferences for really new products. Journal of Marketing Research, 40, 406-420. DOI:10.1509/jmkr.40.4.406.19394
KATZ, J., \& Sugiyama, S. (2006). Mobile phones as fashion statements: Evidence from student surveys in the US and Japan. New Media \& Society, 8, 321. DOI: I0.1 I77//46/44480606/950

KHAN,U., \& Dhar, R. (20I0). Price-framing effects on the purchase of hedonic and utilitarian bundles. Journal of Marketing Research, 47, I090-I099. DOI: I0.I509/jmkr.47.6.1090

KIM, J., Park, Y., Kim, C., \& Lee, H. (20I4). Mobile application service networks: Apple's App Store. Service Business, 8(I), I-27. DOI: |0.1007/s | |628-0|3-0|84-z

KIM, K. J. \& Sundar, S. S. (20I4). Does screen size matter for smartphones? Utilitarian and hedonic effects of screen size on smartphone adoption. Cyberpsychology, Behavior, and Social Networking, 17( 2). DOI: I0.1089/cyber.2013.0492.

KIM, Y., Lee, J., \& Koh, D. (2005). Effects of consumer preferences on the convergence of mobile telecommunications devices. Applied Economics, 37, 817-826. DOI: 10.1080/0003684042000337398.

KLEIN, A., \& Jakopin, N. (20I4). Consumers' willingness-topay for mobile telecommunication service bundles. Telematics and Informatics, 3I(3), 4I0-42I. DOI: 10.10I6/j. tele.2013.11.006

KNOTTS, T., Jones, S., \& Udell, G. (2009). Innovation evaluation and product marketability. Marketing Management Journal, 19, 84-90.

KOZINETS, R. (I997).“I want to believe”:A nethnography of the 'X-Philes' subculture of consumption. Advances in Consumer Research, 24, 470-475.

KOZINETS, R. (2002). The field behind the screen: Using netnography for marketing research in online communities. Journal of Marketing Research, 39, 6I-72. DOI:10.1509/ jmkr.39.I.6I.I8935

KOZINETS, R. (20I0). Netnography: Doing Ethnography Research Online. Thousand Oaks, CA: Sage.

LEE, H. H. \& Hill, J.T. (20I3). Utilitarian and hedonic perceptions of short message service mobile marketing. International Journal of Mobile Communications, II(6), 597-6I6. DOI:10.1504/ijmc.2013.057817

LEE, I. G., Kim, S.Y., Lee, O. S., Lee, H. K., Yeon, S. J., Song,Y.W., \& Kim, J. (20I3). Product orientations and the development strategies of new convergence products: moderating effects of corporate capabilities. Asian Journal of Technology Innovation, 2I (I), 34-5I. DOI: I0.1080/1976I597.2013.8I0950 
LEFTHERIOTIS, I., \& Giannakos, M. N. (20I4). Using social media for work: Losing your time or improving your work? Computers in Human Behavior, 31, 134-I42. DOI:10.1016/j. chb.2013.10.016

LENNON, M. (2010). Monetizing Mobile: Factors Influencing the Development of Mobile Commerce - Korea, China, Japan. Saarbrucken, Germany: Lambert Academic Publishing.

LENNON, M. (20I la). Competitive forces in Japanese mobile telephony: The case of NTT DoCoMo and KDDI. International Journal of Management and Decision Making, I I, 268-283. DOI:10.1504/ijmdm.20II.040703

LENNON, M. (20I l b). EastAsian supply chains:Designer mobile phones. International Journal of Management and Decision Making, II, 284-297. DOI: I 0.I504/ijmdm.20I I.040704

MCCRACKEN, G. (1986). Culture and consumption: A theoretical account of the structure and movement of the cultural meaning of consumer goods. Journal of Consumer Research, 13, 7I-84. DOI: 10.1086/209048.

MCNAUGHTON, D., \& Light, J. (2013). The iPad and mobile technology revolution: Benefits and challenges for individuals who require augmentative and alternative communication. Augmentative and Alternative Communication, 29(2), I07-I |6. DOI: I0.3109/074346|8.20|3.784930

MENG, L. (2005). Self-enhancing through consumption. Advances in Consumer Research, 32, 250-25I.

MITTAL, B. (2006). I, me, and mine - how products become consumers' extended selves. Journal of Consumer Behaviour, 5, 550-562. DOI: 10.1002/cb.202

MUKHERJEE, A., \& HOYER, W. (200I). THE EFFECT OF NOVEL ATTRIButes on product evaluation. Journal of Consumer Research, 28, 462-472. DOI: 10.1086/323733

MUÑIZ, A. M., \& O'Guinn, T. C. (200I). Brand community. Journal of Consumer Research, 27, 4I2-432. DOI: $10.1086 / 319618$

NOWLIS, Stephen M., Mandel, N., \& McCabe, Deborah B. (2004). The effect of a delay between choice and consumption on consumption enjoyment. Journal of Consumer Research, 3I, 502-5I0. DOI: 10.1086/425085.

NUNES, J. (2000). A cognitive model of people's usage estimations. Journal of Marketing Research, 37, 397-409. DOI:I0.I509/jmkr.37.4.397.18788.
NUNES, P., Wilson, D., \& Kambil, A. (2000). The all-in-one market. Harvard Business Review, 78, 19-20.

OKADA, E. (2005). Justification effects on consumer choice of hedonic and utilitarian goods. Journal of Marketing Research, 42, 43-53. DOI:10.1509/jmkr.42.I.43.56889.

OSTASHEWSKI, N., \& Reid, D. (20I0). iPod, iPhone, and now iPad:The evolution of multimedia access in a mobile teaching context. World Conference on Educational Multimedia, Hypermedia and Telecommunications 2010 (pp. 2862-2864). Toronto, Canada:AACE.

PALAZON, M., \& Delgado-Ballester, E. (2013). Hedonic or utilitarian premiums: does it matter?.European Journal of Marketing, 47(8), I 256-I275. DOI: I 0.I I 08/0309056 | 3 I I 3243 I8. Park, C. (2006). Hedonic and utilitarian values of mobile internet in Korea. International Journal of Mobile Communications, 4, 497-508.

PATHAK, J. (2005). Risk management, internal controls and organizational vulnerabilities. Managerial Auditing Journal, 20, 569-577. DOI: $10.2139 / \mathrm{ssrn} .759 \mid 24$.

PIMENTEL, R. W., \& Reynolds, K. (2004). A model for consumer devotion: Affective commitment with proactive sustaining behaviors. Academy of Marketing Science Review, 5, $\mathrm{I}-45$.

REID, D., \& Reid, F. (2007). Text or talk? Social anxiety, loneliness, and divergent preferences for cell phone use. CyberPsychology \& Behavior, 10, 424-435. DOI:10.1089/ cpb.2006.9936.

ROGERS, E. M. (2003). Diffusion of Innovations. New York: The Free Press, 5th edition.

SARIN, S., Sego, T., \& Chanvarasuth, N. (2003). Strategic use of bundling for reducing consumers' perceived risk associated with the purchase of new high-tech products. Journal of Marketing Theory and Practice, II, 7I-83.

SLAMA, M., \& Singley, R. (1996). Self monitoring and valueexpressive vs. utilitarian ad effectiveness: Why the mixed findings? Journal of Current Issues \& Research in Advertising, I8, 39-52. DOI:I0.1080/I064I734.1996.10505050.

SPAID, B. I., \& Flint, D. J. (2014). The meaning of shopping experiences augmented by mobile internet devices. The Journal of Marketing Theory and Practice, 22(I), 73-90. DOI: $10.2753 / \mathrm{mtp}$ 1069-6679220105.

STAKE, R. E. (1995). The Art of Case Study Research. Thousand Oaks, CA: Sage. 
STEIN, M.-K., Galliers, R. D., \& Markus, M. L. (20I3). Towards an understanding of identity and technology in the workplace. Journal of Information Technology, 28(3), 167-182. DOI: $10.1057 /$ jit.2012.32.

STRAUSS, A., \& Corbin, J. (1998). Basics of Qualitative Research. Thousand Oaks, CA: Sage.

TAYLOR, L., Titmuss, R., \& Lebre, C. (1999). The challenges of seamless handover in future mobile multimedia networks. Personal Communications, IEEE, 6, 32-37. DOI:I0.1 109/98.76042I.

TERLUTTER, R., \& Moick, M. (20I3). Convergence and consumer behavior. In Media and Convergence Management, Chapter II, (pp. 163-176). Berlin/Heidelberg: Springer. DOI:I0.1007/978-3-642-36I63-0_II.

VAN DER HEIJDEN, H. (2004). User acceptance of hedonic information systems. MIS Quarterly, 28, 695-704.

VERYZER, R. W., \& Borja de Mozota, B. (2005). The impact of user-oriented design on new product development: An examination of fundamental relationships. Journal of Product Innovation Management, 22, I28-I43. DOI:10.1 I I I/j.07376782.2005.00110.x.

VRDOLJAK, M., Vrdoljak, S., \& Skugor, G. (2000). Fixedmobile convergence strategy: Technologies and market opportunities. Communications Magazine, IEEE, 38, II6-12I. DOI: 10.1 109/35.819904.

YIM, C. K., Tse, D. K., \& Chan, K. W. (2008). Strengthening customer loyalty through intimacy and passion: Roles of customer-firm affection and customer-staff relationships in services. Journal of Marketing Research, 45, 74I-756.

YIN, R. K. (2009). Case Study Research: Design and Methods. Thousand Oaks, CA: Sage. 